\title{
Czesław Brokos
}

\section{„Wtedy czuło się, że się żyje”. Kulisy działalności opozycyjnej w Polsce lat 80. XX w.}

\section{[Czesław Brokos, 'Back Then, You Felt You Were Alive': Behind the Scenes of the Pro-Democratic Opposition in 1980s Poland]}

DOI: $10.26774 /$ wrhm.274

\section{opracowanie Kamil Borecki}

[Wrocław]

(iD https://orcid.org/0000-0003-1502-0357

\begin{abstract}
Czesław Brokos's narrative, which has been supplemented by academic commentary, presents an intimate look at the underground printer's life and activity in 1980 Poland. This witness to history also recalls the names of many of his collaborators, which had hitherto been absent from academic publications.
\end{abstract}

\section{Keywords}

"Lower Silesian Bulletin", Independent Self-Governing Trade Union “Solidarity," anti-communist opposition, Solidarity Regional Strike Committee, Ministry of Public Security, Fighting Solidarity, solidarity strikes in 1980, samizdat, undergorund publications

\section{Słowa kluczowe}

„Biuletyn Dolnośląski”, Niezależny Samorządny Związek Zawodowy „Solidarność”, opozycja antykomunistyczna, Regionalny Komitet Strajkowy „Solidarność”, Służba Bezpieczeństwa, Solidarność Walcząca, strajki solidarnościowe w 1980 r., drugi obieg, pisma bezdebitowe 


\section{Wstęp}

Fenomen „Solidarności” jako wielkiego ruchu społecznego sprzeciwiającego się reżimowi komunistycznemu w Polsce nie zaistniałby bez zaangażowania w opozycję tysięcy ludzi. Często były to osoby z drugiego, a nawet trzeciego planu, o których nie wspomina się na kartach historii. Jedną z takich postaci jest Czesław Brokos, którego zaangażowanie - podobnie jak wielu innych wrocławskich opozycjonistów - datuje się od strajku solidarnościowego w sierpniu 1980 r. Stanął on wówczas na czele strajku we Wrocławskim Przedsiębiorstwie Instalacji Przemysłowych „Instal”, a później został tam przewodniczącym Tymczasowego Komitetu Założycielskiego „Solidarność". Do jego głównych zadań należało pozyskiwanie i zapisywanie nowych członków do „Solidarności”, tworzenie struktur nowego związku zawodowego we wrocławskim „Instalu” oraz w jego oddziałach na terenie Dolnego Śląska. Utrzymywał także kontakt z Międzyzakładowym Komitetem Założycielskim „Solidarności” i z czasem został etatowym działaczem „Solidarności” w swoim zakładzie pracy. Na początku 1981 r. zorganizował wybory władz związkowych w „Instalu”, w wyniku których został ich wiceprzewodniczącym. W momencie wprowadzenia stanu wojennego nie zaniechał aktywności wymierzonej przeciwko władzom komunistycznym i przeszedł do konspiracji, w podziemiu posługując się pseudonimem „Kuba”.

Konspiracyjna działalność Czesława Brokosa polegała na drukowaniu i kolportowaniu nielegalnej prasy oraz ulotek i wpisywała się w potężną sieć podziemnego drukarstwa ${ }^{2}$, które musiało odrodzić się po szoku wprowadzenia stanu wojennego i licznych aresztowaniach wśród działaczy opozycji. W krótkim czasie podjęto wiele inicjatyw wydawniczych, publikując prasę i książki, mimo ryzyka szczególnych w stanie wojennym represji względem podziemnych drukarzy (groziło im nawet do ośmiu lat więzienia, co zniechęciło wiele osób do takiego działania). Szacuje się, że w latach 80. xx w. w podziemiu aktywnych było w Polsce kilkadziesiąt tysięcy opozycjonistów³ , a wśród nich Czesław Brokos,

1 Archiwum Instytutu Pamięci Narodowej Oddział Wrocław (dalej: A IPN wr), sygn. 024/8851, Uzupełnienie meldunku nr 215 do Sprawy Operacyjnego Rozpracowania krypt. „Krzew”, 14 V 1986 r., k. 27.

2 Szacuje się, że w latach 1976-1989 w podziemiu w Polsce ukazało się ok. 6,5 tys. książek i ok. 5,5 tys. tytułów prasowych. Był to jeden z największych podziemnych „rynków” wydawniczych wśród państw bloku sowieckiego oraz przykład i inspiracja dla ruchów opozycyjnych w innych krajach, znajdujących się pod dominacją zSRR. Zob.: J. Olaszek, Drugi obieg wydawniczy w PRL i samizdat w innych państwach bloku sowieckiego: podobieństwa, różnice, wzajemne wpływy, [w:] Drugi obieg w PRL na tle samizdatu w państwach bloku sowieckiego po 1956 r., red. P. Gasztold-Seń, N. Jarska, J. Olaszek, Warszawa 2016, s. 16.

3 J. Olaszek, Rewolucja powielaczy. Niezależny ruch wydawniczy w Polsce 1976-1989, Warszawa 2015, s. 207-212. 
koordynujący wówczas we Wrocławiu prace kilku punktów, w których prowadzona była nielegalna poligrafia. Warto wspomnieć, że nie otrzymywał na tę działalność środków finansowych i musiał je organizować na własną rękę. Drukował przy tym nie tylko dla Regionalnego Komitetu Strajkowego „Solidarność”, ale także dla Solidarności Walczącej, a działalność poligraficzną przerwał ostatecznie w 1986 r. Jednym z powodów było to, że konspiracyjni zwierzchnicy Czesława Brokosa postanowili zastąpić druk za pomocą powielaczy na rzecz sitodruku. Chciano w ten sposób uzyskać lepszą jakość drukowanych materiałów. Zbiegło się to w czasie ze wzrostem obaw Czesława Brokosa o bezpieczeństwo rodziny, dlatego postanowił, że zmiana metod drukowania będzie dogodnym momentem na odejście od poligrafii. Nie oznaczało to jednak zerwania z konspiracyjnymi strukturami. Nadal angażował się w ich działalność m.in. poprzez kolportaż różnego rodzaju druków. Z „Solidarnością? zerwał w 1989 r., zniechęcony rezultatami obrad okrągłego stołu.

Prowadzenie nielegalnej poligrafii wiązało się z licznymi zagrożeniami zarówno dla samego konspiratora, jak i jego rodziny, czego doświadczył również Czesław Brokos. Dyrekcja „Instalu” podejmowała próby zwolnienia go z pracy, znalazł się również na celowniku Służby Bezpieczeństwa, której funkcjonariusze, wedle relacji Czesława Brokosa, włamali się do jego domu'. Aresztowania uniknął tylko przez przypadek i nie był nigdy przesłuchiwany. Jego rozpracowywanie prowadzono od 1986 r. w ramach operacji „Krzew” w Wydziale III Wojewódzkiego Urzędu Spraw Wewnętrznych we Wrocławiu. Funkcjonariuszom SB udało się ustalić, że osobą posługującą się konspiracyjnym pseudonimem „Kuba” był właśnie Czesław Brokos. Miał on być obserwowany i śledzony w celu „ujawnienia jego konspiracyjnych kontaktów oraz udokumentowania prowadzonej przez niego nielegalnej działalności"7. Według Brokosa dane w dokumentacji Instytutu Pamięci Narodowej, dotyczące m.in. adresu zamieszkania czy marki samochodu,

4 Regionalny Komitet Strajkowy Nszz „Solidarność” Dolny Śląsk powstał we Wrocławiu w konspiracji po wprowadzeniu stanu wojennego, zob.: W. Sawicki, Regionalny Komitet Strajkowy NSZZ „Solidarnośc”" Dolny Śląsk. XII 1981 - VI 1982, Wrocław 2011.

5 Solidarność Walcząca powstała w wyniku rozłamu w R ks „Solidarność” w czerwcu 1982 r., a na jej czele stał Kornel Morawiecki. Zob.: G. Surdy, K. Brożek, Solidarność Walcząca, Warszawa 2020; Solidarność Walcząca w dokumentach, t. I: w oczach sB, red. Ł. Kamiński, W. Sawicki, G. Waligóra, Warszawa 2007. Czesław Brokos nie był członkiem Solidarności Walczącej, pozostając w strukturach R KS „Solidarność”.

6 Brokos podejrzewa, że włamania dokonali funkcjonariusze sв, na co wskazują pewne poszlaki w archiwum IPN: w jednym z meldunków operacyjnych, powstałym niedługo po włamaniu do mieszkania Cz. Brokosa, pojawiła się informacja, że „Kuba” posiadał 190 matryc; A IPN Wr, sygn. 024/8851, Uzupełnienie meldunku nr 203 do Sprawy Operacyjnego Rozpracowania krypt. „Krzew”, 8 V 1986 r., k. 28.

7 AIPN wr, sygn. 024/8851, Uzupełnienie meldunku nr 215 do Sprawy Operacyjnego Rozpracowania krypt. „Krzew”, 14 V 1986 r., k. 27. 
jaki posiadał „Kuba”, były w 1986 r. już nieaktualne. Może to świadczyć o tym, że rozpracowanie Czesława Brokosa było wówczas niepełne lub we wstępnej fazie, a z dalszych meldunków „Kuba” w ogóle zniknął, co mogło mieć związek z zaprzestaniem nielegalnego drukowania w tym właśnie $1986 \mathrm{r}$.

W swojej relacji Czesław Brokos wspominał przede wszystkim o trudach pracy konspiracyjnej, ukazując ją niejako „od kuchni”, skupiając się przede wszystkim na konspiracyjnym drukowaniu. Wśród metod powielania, które sam stosował i w jakich się szkolił, znajdowało się drukowanie na ramce. Polegało ono na czasochłonnym powielaniu tekstu za pomocą matrycy białkowej, na którą tekst nanoszono na maszynie do pisania, a następnie matryca była umieszczana na drewnianej ramce i pokrywana farbą. Aby przyspieszyć proces, pracowano najczęściej parami: pierwsza osoba opuszczała i podnosiła ramkę oraz wyciągała zadrukowany papier, a druga wałkiem lub raklą rozprowadzała farbę na matrycy. Aby jeszcze bardziej usprawnić działanie, wrocławscy opozycjoniści wprowadzili mechanizm automatycznego podnoszenia ramki, wykorzystując do tego np. gumkę, co pozwalało zaoszczędzić jeden ruch na każdą z czasem i kilku tysięcy zadrukowywanych stron'. Od 1983 r. Czesław Brokos używał do druku elektrycznych powielaczy bębnowych, które były nielegalnie sprowadzane z Zachodu lub kupowane na czarnym rynku. Ich zaletą była większa wydajność niż w przypadku ramki: z jednej matrycy na powielaczu można było uzyskać do 6 tys. kopii, podczas gdy na ramce - od 500 szt. do 4 tys. Wadą zaś był wydawany przez nie przy pracy dźwięk, dlatego konieczne było wyciszenie maszyny bądź pomieszczenia, w którym pracowała?

Relacja Czesław Brokosa pokazuje, jak dużo poświęcenia wymagała działalność w podziemiu, jak bardzo była czasochłonna i przede wszystkim niebezpieczna. Miewała też jednak jasne strony - podczas pracy w jednym z konspiracyjnych lokali Brokos spotkał swoją przyszłą żonę, a samo nielegalne drukowanie wspomina pozytywnie: było to bardzo intensywne doświadczenie, ale „wtedy czuło się, że się żyje".

Pracy konspiracyjnej Czesław Brokos nie prowadził sam i w swojej relacji wspomina z nazwiska wielu współpracowników, również osoby do dzisiaj bliżej nieznane. Jest to kolejny dowód na prawdziwość tezy o opozycji antykomunistycznej lat 80. xx w. jako masowego ruchu, opierającego się na tysiącach głęboko wówczas zakonspirowanych ludzi. Wydaje się, że rejestrowanie ich relacji to praktycznie jedyna metoda badań, która pozwoli dowiedzieć się czegoś więcej o ich

8 Więcej na temat druku na ramce zob.: K. Dworaczek, Podziemnie drukarstwo we Wrocławiu na przykładzie największych inicjatyw wydawniczych, „Dzieje Najnowsze”, R. 48 (2016), nr 4, s. 143-144; K. Grzelczyk, Solidarność drukująca. Wrocławscy drukarze podziemni, Wrocław 2013, s. 134-136; Sz. Rudka, Poza cenzurq. Wrocławska prasa bezdebitowa 1973-1989, Warszawa-Wrocław 2001, s. 55-57. 
osobistym zaangażowaniu, pracy opozycyjnej i jej rezultatach, a także odtworzyć możliwie pełną listę nazwisk osób, które przyczyniły się do upadku systemu komunistycznego w Polsce.

Prezentowana poniżej relacja została zarejestrowana w Centrum Historii Zajezdnia we Wrocławiu 11 lutego 2020 r. w ramach projektu „Zajezdnia strajkuje” realizowanego w Ośrodku „Pamięć i Przyszłość” i była to pierwsza złożona przez Czesława Brokosa relacja o jego konspiracyjnej działalności. Celem wspomnianego projektu było poszerzenie wiedzy na temat strajku solidarnościowego w sierpniu 1980 r. we Wrocławiu, w szczególności w zajezdni autobusowej nr viı, gdzie mieściło się strajkowe centrum wraz z Międzyzakładowym Komitetem Strajkowym $^{10}$. W badaniach nad tym zagadnieniem przeprowadzono kwerendy archiwalne, a nagrywając relacje świadków historii, posłużono się metodą wywiadu narracyjno-biograficznego, po swobodnej narracji o historii życia rozmówcy, zadając pytania z wcześniej przygotowanego kwestionariusza ${ }^{11}$. W przypadku tego projektu dotyczyły one przede wszystkim przebiegu strajku z sierpnia $1980 \mathrm{r}$.

Poddany edycji źródłowej zapis relacji został tu podzielony na dwie części. Pierwsza zawiera fragmenty swobodnej narracji Czesława Brokosa i odpowiedzi na doprecyzowujące pytania prowadzącego wywiad (część tę podzielono na cztery tematyczne fragmenty), druga zaś ma formę ustrukturyzowanego wywiadu, przeprowadzonego według kwestionariusza projektu. Pytania osoby przeprowadzającej rozmowę zostały zapisane kursywą.

Struktura prezentowanej treści nie oddaje w pełni chronologii wypowiedzi świadka: niektóre fragmenty wypowiedzi świadka zostały przesunięte w inne miejsce. Celem takiego zabiegu było zachowanie odpowiedniej chronologii, która w opowieści bywała zaburzona. Wszelkie usunięte z edycji zdania i słowa (podobnie jak dopowiedzenia) zostały zaznaczone nawiasem kwadratowym z wielokropkiem, co ułatwić ma odbiór tekstu pisanego ${ }^{12}$. Z tekstu usunięto niewnoszące nic do treści źródła powtórzenia i urwane zdania, a także niezwiązane z tematem dygresje, które nadmiernie rozbijały główną narrację. Dołożono przy tym wszelkich starań, aby nie zmienić sensu wypowiedzi świadka historii oraz zachować w jak największym stopniu oryginalny charakter wypowiedzi i specyfikę języka

10 Strajk we Wrocławiu trwał w dniach 26 viı I - 1 Ix 1980 r. Więcej na ten temat zob.: Ł. Kamiński, NSZZ „Solidarność” Region Dolny Śląsk, [w:] NSZZ „Solidarność” 1980-1989, tom 6: Polska południowa, red. Ł. Kamiński, G. Waligóra, Warszawa 2010, s. 321-330; J. Kordas, A. Kudłaszyk, Sierpień '8o na Dolnym Śląsku, Wrocław 1997, s. 91-197; W. Suleja, Solidarność na Dolnym Śląsku 1980-2010, Wrocław 2010, s. 29-52; L. Ziątkowski, Na drodze do Solidarności. Wrocław w walce o demokrację i niepodległość 1976-1980, Wrocław 2010, s. 78-122.

11 Szerzej na temat metody biograficznej zob. m.in.: K. Kaźmierska, K. Waniek, Autobiograficzny wywiad narracyjny. Metoda - technika - analiza, Łódź 2020.

12 Nie zaznaczano jedynie dodanych końcówek urwanych słów. 
mówionego rozmówcy. W ramach edycji relację opatrzono przypisami, objaśniającymi w niezbędnym zakresie tożsamość osób występujących w relacji oraz wydarzenia wspominane przez świadka. $Z$ powodu licznych, wymienionych powyżej, ingerencji edytorskich relacja została poddana autoryzacji, jednak Czesław Brokos nie miał do niej żadnych zastrzeżeń. Pełna treść nagrania wraz z transkrypcją znajduje się w Archiwum Historii Mówionej Ośrodka „Pamięć i Przyszłość”13.

\section{Relacja Czesława Brokosa Część I}

\section{Strajk i legalna działalność w „Solidarności”}

Właściwie to moje pierwsze [...] spotkanie $\mathrm{z}$ ruchem opozycyjnym było jeszcze przed Sierpniem, ponieważ [...] do dzisiaj mam w swoich zbiorach „Biuletyn Dolnośląski"14 sprzed sierpnia [19]80 r. [...] Ale jak strajki się rozpoczęły na Wybrzeżu, [to] podniecenie było już u mnie [widoczne] ${ }^{15}$. [...] Pracowałem wtedy we Wrocławskim Przedsiębiorstwie Instalacji Przemysłowych „Instal” na [ul.] Swojczyckiej 38. To był zakład instalacji przemysłowych - budowa fabryk, sieci ciepłowniczych na całym regionie dolnośląskim. U nas mieliśmy oddziały rozrzucone po [...] całym regionie dolnośląskim. Zakład liczył około 1800 pracowników, co się zmieniało, ale tak mniej więcej było. I u nas strajk rozpoczął się, jak pamiętam, 27 sierpnia na jednym z oddziałów, tj. na tak zwanych warsztatach, zapleczu, gdzie [...] jeden dział stanął. Natomiast ja wtedy pracowałem w biurowcu tzw. dyrekcji [...]. Całość zakładu [stanęła] dopiero na następny dzień. Rano przyszedłem [...] do pracy z jeszcze dwoma [pracownikami] z działu zaopatrzenia [...]. Żeśmy po biurach przelecieli i zwołaliśmy zebranie całej dyrekcji na świetlicy [...]. Bo u nas było tak, że jak dyrekcja stanie, to stanie cały zakład. Natomiast jeżeli dyrekcja nie stanie, to to, że [...] gdzieś tam jedna hala stanęła tylko, zaplecze - to nie odzwierciedlało to wcale tego, że zakład staje, bo budowa nie wie [co się dzieje]. [...] Zależało nam na tym, żeby stanęła dyrekcja, to wtedy staje od razu cały zakład. I zwołaliśmy ludzi do świetlicy. I po moim przemówieniu [...] ogłosiliśmy strajk, że przyłączamy się do strajku. [Zastanawialiśmy się,] kto [powinien wejść] do komitetu strajkowego. No to... od razu automatycznie zostałem wybrany [...]

13 Archiwum „Ośrodka Pamięć i Przyszłość”, Archiwum Historii Mówionej, sygn. PL opip III-1-8-9, Relacja Czesława Brokosa, 11 II 2020 r., Wrocław (sporządził Kamil Borecki).

14 Konspiracyjne pismo wychodzące we Wrocławiu w latach 1979-1990. Nakład jego sięgał ok. 10 tys. egzemplarzy. Zob.: L. Ziątkowski, op. cit., s. 58-60.

15 Strajk w Stoczni Gdańskiej im. W. Lenina rozpoczął się 14 VIII 1980 r. rano. Dwa dni później został uformowany tam Międzyzakładowy Komitet Strajkowy, który 17 viı opublikował 21 postulatów. Więcej na temat strajku w Stoczni Gdańskiej zob.: A. Friszke, Rewolucja Solidarności 1980-1981, Kraków 2014, s. 27-73. 
jako przewodniczący tego komitetu strajkowego. Żeśmy strajk okupacyjny [zorganizowali] - na zasadzie takiej, że ma stać... [cały zakład]. Na noc zostawała tylko część załogi. Nie było tak, żeby cała załoga była, tylko żeśmy straż [zostawiali] [...]. I [...] [został] wysłany przedstawiciel do [...] zajezdni ${ }^{16}$. Nie pamiętam jego nazwiska, [...] twarz jego pamiętam, bo [on] był narodowości romskiej ${ }^{17}$. [...] Pamiętam natomiast, że on po strajkach nie przejawiał [większej] inicjatywy do jakiejś tam działalności. Nie dał się tam [zapamiętać] [...], bo tych, którzy byli w komisji, w TKz-cie tak zwanym - Tymczasowej Komisji Założycielskiej „Solidarności”, którzy się zaangażowali, to [...] bardziej pamiętam [...]. Tak było [...] do podpisania porozumień.

Po rozwiązaniu strajku przekształciliśmy [się] zaraz [...] [w] TKz i [...] zostałem jej przewodniczącym oraz [...] zająłem się organizowaniem „Solidarności” [w „Instalu"]. [...] Codziennie byłem na [...] placu, obecnie [...] Solidarności, [...] wtedy placu Czerwonym ${ }^{18}$. [...] [Uczestniczyłem] w tych spotkaniach, jeszcze pamiętam, jak [...] żeśmy [je] organizowali, jak zapisywaliśmy [nowych członków]. [...] Robiłem zebrania w poszczególnych działach u nas [w „Instalu”] [...]. [Organizowałem] spotkania i zapisy. Tak, że [...] do końca roku [1981], pamiętam, [...] to [...] 90 procent załogi zapisało się do [...] związku. [...] Były próby torpedowania tego - [...] wysyłano mnie w delegacje. [...] [Na przykład] na tydzień pojechałem do Polkowic. [...] Więc [...] wykorzystywałem [...] tę sytuację na [zorganizowanie] zebrania. [...] Ale to było [uciążliwe] [...] i wystąpiliśmy do dyrektora o oddelegowanie mnie do działalności związkowej i [od tego czasu] byłem na etacie [...] w zakładzie, z tym że [...] oddelegowany do działalności związkowej. [...] Dyrektor był pod presją [...], bo [...] [jako] „Solidarność” żeśmy dosyć [...] prężnie działali [...] w zakładzie i do [...] wyborów pełniłem funkcję [...] przewodniczącego т kz-u. [...] Organizowałem [także] wybory [przewodniczącego w „Instalu"] i, nie pamiętam w tej chwili, chyba gdzieś [...] w styczniu [je] [...] przeprowadzałem [...]. Uzgodniliśmy [...] wtedy [...] i [...] zaproponowaliśmy [...] załodze na zebraniach, że kolega Władek Puzanowski ${ }^{19}$ [zostanie przewodniczącym]. Wcześniej się nie [...] bardzo

Chodzi o zajezdnię autobusową nr viı przy ul. Grabiszyńskiej we Wrocławiu.

Osoba bliżej nieznana.

Tuż po zakończeniu strajku м кs przekształcił się w Międzyzakładowy Komitet Założycielski, który otrzymał od władz siedzibę na ówczesnym pl. Czerwonym 1/3/5 we Wrocławiu (dziś pl. Solidarności). Pomimo niewielkich rozmiarów (kilka małych pokoi) 4 września, podczas zebrania informacyjnego, przybyło tam ok. 3 tys. delegatów z różnych zakładów pracy; W. Suleja, op. cit., s. 58. W tym samym miejscu znajduje się obecnie Zarząd Regionu Dolny Śląsk nszz „Solidarność”.

Władysław Puzanowski - od początku 1981 r. przewodniczący „Solidarności” w „Instalu”. Po wprowadzeniu stanu wojennego wycofał się z działalności opozycyjnej i zwolnił się z „Instalu”. Skontaktował Cz. Brokosa z Leszkiem Bielakiem, dzięki czemu ten pierwszy zaczął konspiracyjnie drukować (informacje podane na podstawie relacji Czesława Brokosa). 
angażował, ponieważ akurat w czasie strajku [...] był na urlopie. [...] Taką decyzję żeśmy podjęli, [...] żeby został przewodniczącym związku, natomiast ja zostałem wiceprzewodniczącym.

Byłem na etacie związkowym [...]. [Od] czarnej roboty [...]. Jak [związek został] przeniesiony [...] na [ul.] Mazowiecką ${ }^{20}$, [...] to też codziennie rano jechałem [tam], [...] po taśmy do gazetki, po ulotki, bo trzeba było dostarczyć [...] załodze. [...] Ale ten czas [...] euforii takiej, [...] po strajkach zaraz, [...] czas organizowania związku, [...] był [...] taki właśnie euforyczny. [...] Wiadomo, taka działalność związkowa [...] [polegała m.in. na] walce [...] o wolne soboty i o sprawy pracownicze. [...] Pamiętam, to [...] nie była praca na 8 godzin, to był [...] nienormowany czas pracy. [...]

\section{Stan wojenny i początek działalności konspiracyjnej}

I tak był do grudnia [1981 r.]. Pamiętam, jak zbliżał się [...] ten konflikt ${ }^{21}$, to my żeśmy podjęli [...] uchwałę, że w razie stanu wojennego [...] ogłaszamy strajk [...]. I przegłosowaliśmy tę uchwałę i [strajk] miał być automatycznie [wprowadzony]. Natomiast [...] nie udało [się tego przeprowadzić], [gdyż spotkało się to ze] [...] sprzeciwem, [...] nawet [ze strony] przewodniczącego. [...] [Wobec tego] [...] zrobiliśmy głosowanie. [...] Odbyło się [...] 14 grudnia rano. W zasadzie [...] ja zebrałem załogę [...] [w] świetlicy i ogłosiłem, że przystępujemy do strajku. [...] Poszła natomiast uchwała, żeby przeczekać, zobaczyć, wysłać po informacje [...] [z] innych zakładów [...], zobaczyć, co się [tam] dzieje, [...] żeby wstrzymać się. No i 13 [grudnia] już nie przystąpiliśmy do strajku [...] okupacyjnego, natomiast ja [...] schowałem się na zakładzie [...] i trzy dni ukrywałem się. [...] Pierwsze trzy dni stanu wojennego [...] tak [wyglądały]: 1 dzień - byłem na zakładzie, ale byłem ukryty wśród pracowników, ponieważ [...] była obawa, że [mnie] zgarną. [...] Z tym, że mieliśmy w porządku dyrektora, [...] [gdyż wcześniej nastąpiła] [...] zmiana [dyrektora] [...]. [Nowego] dyrektora ogłosiliśmy za czasów legalnej „Solidarności”. [...] [Wygrał wtedy] wychowanek zakładu. [...] [Przyszedł] po studiach [...], później [...] stopniowo [...] awansował i [...] wystartował na dyrektora. [...] Powiedzmy, [że] znaliśmy się [...] i mieliśmy taki względny, no dobry [...] układ, że on mi nie był przeciwnikiem. [...] I po trzech dniach [...] przysłał mi informację przez ludzi [...], że: „gwarantuje, że rozmawiał" - to znaczy [...], żebym podjął pracę [i] [...] nie będę aresztowany. [...] Podjęliśmy decyzję, że co będzie, to będzie, wychodzę. [...] Na czwarty dzień przyszedłem normalnie do pracy. [...] Jako że byłem [jednym z] przywódców związku [w „Instalu”], [to] dalej głosiłem swoje poglądy. Głośno i oficjalnie. zlokalizowaną w centralnej części miasta (obecnie osiedle Przedmieście Oławskie). 
Były różne [...] sytuacje, [nawet] i przezabawne [...]. [Niektórzy] donosili, była [...] walka plakatowa - [...] ściągali plakaty, my żeśmy nalepiali z powrotem. [...] Była [także inna forma] [...] uświadamiania [...] [w formie] gazetek.

I zaangażowałem się właśnie w działalność [w podziemiu], [...] szukałem dojścia do poligrafii, żeby można było [drukować]. [...] Podjąłem współpracę właśnie [...] z Kornelem [Morawieckim] ${ }^{22}$. [...] Bo to Kornel był na czele [...] redakcji „Z Dnia na Dzień" ${ }^{\prime 2}$. Od niego [...] dostałem ramkę ${ }^{24}$ [...], na której był drukowany „Biuletyn Dolnośląski” jeszcze przed [19]80 r. Stara historyczna ramka, była juź [...] używana 1000 razy [...]. Dostałem tę ramkę i [...] właśnie na [niej] Leszek Bie$l^{2} k^{25}$ pierwszy dzień uczył mnie drukować. Ja nie miałem zielonego pojęcia [...] o druku, o ramce. [...] Nie robiłem nigdy tego. [...] Na drugie spotkanie przyszedł "Jarek", [...] [to] pseudonim [...], a [był to] [...] Arek Dobrowolski ${ }^{26}$, i wtedy robiliśmy razem „Z Dnia na Dzień”. [...] [Później, gotowe gazety] zabierałem w torbę i przenosiłem z miejsca, gdzie drukowaliśmy, na drugie miejsce - na mieszkanie, na [tzw.] skrzynkę, gdzie przychodzili [...] łącznicy [i zabierali je] na zakłady. I taką moją pierwszą skrzynką byli [...] Józef i [...] Janina Gliwowie ${ }^{27}$. [Mieszkali] [...] na ulicy Kromera 11 mieszkania 2. [...] [Już] świętej pamięci, nie żyją. [...] Będę występował o nadanie im statusu działacza opozycji, bo oni przez te wszystkie lata, [...] od początku stycznia [19]82 r. do końca [...], byli zaangażowani. [...] Byli [też] kurierami, u nich [...] [była] skrzynka, [na] którą żeśmy przekazywali [...] różne rzeczy. [...] Oni obydwoje pracowali w „Instalu”. Bo na początku to opierałem dużo się o ludzi pewnych, [...] których gdzieś tam znałem z „Instalu”, [...] którym mogłem [...] zaufać. [...] Wiedziałem komu mogę zaproponować [...] działanie.

Kornel Morawiecki (1941-2019) - wrocławski działacz opozycji antykomunistycznej, przywódca Solidarności Walczącej. Od 1979 r. redaktor naczelny „Biuletynu Dolnośląskiego”, od 1981 r. konspiracyjnie redagował „Z Dnia na Dzień”, a od 1982 r. „Solidarność Walczącą”. Zob.: A. Adamski, Kornel, Wrocław 2007; A. Adamski, M. Łątkowska, Kornel Morawiecki, [w:] Encyklopedia „Solidarności”: opozycja w PRL 1976-1989, red. M. Łątkowska, t. 1, Warszawa, Katowice 2010, s. 288-289.

23 Opozycyjne pismo wydawane we Wrocławiu w latach 1981-199o. Początkowo wychodziło pod nazwą „Serwis Informacyjny "Solidarność»". Był to periodyk o charakterze informacyjnym wydawany przez wrocławski Międzyzakładowy Komitet Założycielski, po wprowadzaniu stanu wojennego wydawany konspiracyjnie. Nakład pisma sięgał ok. 45 tys. egzemplarzy, wydania specjalne zaś - ok. 100 tys. Zob.: Sz. Rudka, op. cit., s. 206-208. Chodzi o przyrząd służący do drukowania.

25 Leszek Bielak - w latach 1982-1983 szef kolportażu R KS NSzz „Solidarność” Dolny Śląsk.

26 Arkadiusz Dobrowolski - wrocławski działacz opozycyjny. W latach 1981-1985 współpracownik R KS NSzz „Solidarność” Dolny Śląsk. W jego mieszkaniu drukowane były takie tytuły, jak „Biuletyn Informacyjny”, „Solidarność Dolnośląska” czy „Z Dnia na Dzień”, zob.: E. Chabros, Arkadiusz Dobrowolski, [w:] Encyklopedia „Solidarności”. Opozycja w PRL 1976-1989, red. J. Olaszek, t. 4, Warszawa 2020, s. 68-69. 
[...] [Drukowałem] w różnych miejscach, [...] [m.in.] z Baśką Sarapuk ${ }^{28}$. [...] Później [...] przeniosłem [się] [...] na [ul.] Nowodworską. [...] Tam [poznałem moją] późniejszą małżonkę ${ }^{29}$. [...] [Właściwie] poznaliśmy się [...] u niej [podczas] druku. [...] [Początkowo] dostawałem od razu gotowe matryce [...], miałem ramkę [...] i papier, a później [sam już] organizowałem [materiały do druku] [...]. [Matrycę pisała mi] ta babka ${ }^{30}$, u której się trzy dni ukrywałem ${ }^{31}$, na ulicy Jackowskiego 20. [Wówczas była już emerytką, ale wcześniej pracowała] [...] u nas [...] w „Instalu”. [...] Była [...] tak zwaną kierowniczką hali maszyn, [specjalistką od] [...] pisania na maszynie. [...] [Wobec tego] [...] zaangażowałem ją zaraz do pisania matryc [...] dla Rks-u [...] i [później] dla [Solidarności] Walczącej. [...] [Matryce pisała także] Małgosia Pruchnicka, [...] później Brokos, [...] u [której w mieszkaniu także] drukowaliśmy.

[...] W czerwcu [19]82 r. [...] dostałem [propozycję], właściwie Arek [...] przekazał mi zapytanie Kornela, czy nie przeszedłbym do nich ${ }^{32}$. [...] Ponieważ ja czułem się dalej związkowcem, [to formalnie nie chciałem przejść]. [...] [Odpowiedziałem, że] ja dalej jestem w RKs-ie, bo [...] jestem związkowcem, [także u siebie] [...] w zakładzie. Chcę być w Rks-ie, drukować „Z Dnia na Dzień”, ale do kiedy trzeba będzie, będę drukował [...] również „Walczącą" ${ }^{33}$. I drukowałem na tej samej ramce i „Z Dnia na Dzień” i od początku „Walczącą". [...] Później, jak „Walcząca” przeszła w większości na sitodruk, to ja już nie drukowałem.

[...] Chyba od [19]83 r. [drukowałem na powielaczach ${ }^{34}$ [...]. [Kiedy] przyszedł [...], ten pierwszy ${ }^{35}$ [...], to go [...] [wziąłem] i drukowali na nim Zbyszek i Marylka Gajkowie $^{36}$ na [ul.] Grudziądzkiej. Drukowaliśmy tam „Z Dnia na Dzień” i „Walczącą" [...] [oraz] „Obecność" ${ }^{37}$ - [...] to miesięcznik [lub] kwartalnik [...] społecz-

28 Barbara Sarapuk (1940-2015) - działaczka „Solidarności” oraz Solidarności Walczącej. Zajmowała się konspiracyjnym drukiem. Zob.: K. Dworaczek, Chodziło mi o Polskę. Barbara Sarapuk 1940-2015, Wrocław 2016.

29 Chodzi o Małgorzatę Brokos z d. Pruchnicką.

30 Osoba bliżej nieznana.

31 Mowa tu o trzech pierwszych dniach stanu wojennego.

32 Do Solidarności Walczącej.

33 Właściwie „Solidarność Walcząca” - konspiracyjne pismo wydawane we Wrocławiu w latach 1982-1990 przez Solidarność Walczącą, redagowane m.in. przez Kornela Morawieckiego, w nakładzie ok. 25 tys. egzemplarzy. Zob.: Sz. Rudka, op. cit., s. 397.

34 Chodzi o elektryczne powielacze bębnowe.

35 Prawdopodobnie został przekazany przez Arkadiusza Dobrowolskiego.

36 Zbigniew Gajek - konspiracyjny drukarz. Członek Inicjatywy Wydawniczej „Aspekt”, zob.: Sz. Rudka, op. cit., s. 37.

37 Pismo konspiracyjne wydawane we Wrocławiu w latach 1983-1988 przez Inicjatywę Wydawniczą „Aspekt". Pomimo że posiadało podtytuł „niezależne pismo literackie”, jego profil nie był ściśle określony. Zob.: Sz. Rudka, op. cit., s. 370-377. 
no-kulturalny. Czasopismo [...] to [...] wydawali [...] ludzie z politechniki [...] chyba. [...] Później drukowałem [...] koło Teatru Współczesnego, [...] na [...] ulicy Rzeźniczej [...] chyba, [u małżeństwa] [...] Ciok ${ }^{38}$. [...] [Początkowo drukowaliśmy tam na ramkach], później [...] na [tym] powielaczu. [...] [Następnie miałem drukarnię u] wspaniałej, [...] [trzeba] ją wspomnieć, pani babci Reni ${ }^{39}$ na Lelewela 17. [...] Wtedy miałem już dwa powielacze: [...] jeden u babci Reni [...] i w tej samej bramie, [...] nie miałem [wtedy innego] lokalu, [...] piętro wyżej chodził drugi powielacz, [...] u sąsiadki, [...] takiej Ani ${ }^{40}$, wiem, że młoda [była]. [...] Pamiętam, [że] [...] u babci drukował Andrzej Polechoński ${ }^{41}$ i... o! Zdzisław Ciok ${ }^{42}$. [...] Tam, u babci Reni, [...] wydałem książkę w zasadzie [...] pod nazwą „Wydawnictwo Victoria”" jako Tak się nie godzi ${ }^{44}$. [...] To jest książka wydrukowana na powielaczu, prosto złożona, jak najprościej, bo takie warunki. [...] Nie umieliśmy składać za bardzo książek. [...], ale ponieważ miałem nagranie procesu Bednarza ${ }^{45}$ na taśmie magnetofonowej i odsłuchiwaliśmy [je]. Zresztą to Małgosia (wtedy jeszcze Pruchnicka) [...] odsłuchiwała [to nagranie] z 1000 razy, bo było tak niewyraźne, bo to było na sali [sądowej] [...] ukrytym magnetofonem nagrywane. Więc trzeba było się wsłuchiwać, zrozumieć. No więc ona odsłuchiwała, pisała matrycę i żeśmy drukowali. [...] Miałem przynieść [tę książkę na spotkanie], [...] bo mam jeszcze [...] [egzemplarz] wydany taką techniką. [...]

Wtedy jechaliśmy właśnie na dwóch powielaczach, [...] otrzymywałem tylko [...] tekst na przebitce i leciałem. [...] Resztą [...] zajmowała się ta [...] [moja] grupa. [...] Papier zdobywaliśmy z różnych źródeł. To było tak, że gdzieś, ktoś [dawał] sygnał, [że] ktoś ma ryzę papieru. [...] Organizowano [też zbiórki] po różnych zakładach [...]. Pamiętam również, [jak] [...] dostałem informację, nieważne było od kogo, [...] poprzez jakiegoś łącznika, że jest gdzieś do odebrania [...] papier.

38 Osoby bliżej nieznane.

39 Osoba bliżej nieznana.

40 Osoba bliżej nieznana.

41 Osoba bliżej nieznana.

42 Zdzisław Ciok - drukował konspiracyjnie na powielaczach. Odsunięty od poligrafii przez Cz. Brokosa, gdyż angażował się również w inne sfery działalności opozycyjnej, co miało negatywnie wpływać na zachowanie wymogów konspiracyjnych (informacje podane na podstawie słów $\mathrm{Cz}$. Brokosa).

43 Wydawnictwo funkcjonujące we Wrocławiu w latach 1983-1984. Następnie przekształciło się jedną z większych wrocławskich oficyn wydawniczych - Spółdzielnię Wydawniczą Profil kierowaną przez Antoniego Wójtowicza. Zob.: K. Dworaczek, Podziemne drukarstwo we Wrocławiu..., s. 151.

44 Tak się nie godzi - zapis procesu Piotra Bednarza, Wrocław 1984. W 2011 r. wydana została książka ukazująca sylwetkę Bednarza o podobnym tytule, zob.: K. Kaczorowska, W. Suleja, Tak się nie godzi. Piotr Bednarz (1949-2009), Wrocław 2011.

45 Piotr Bednarz (1949-2009) - wrocławski działacz opozycji antykomunistycznej. Od 5 X 1982 r. przywódca RKS NSZZ „Solidarność” Dolny Śląsk. Został aresztowany 7 XI 1982 r. 
[...] Nie wnikałem w szczegóły [...], kto tam, co i jak, tylko trzeba było zorganizować transport, przerzucić. To [...] woziłem [...] [z ul.] Zachodniej, [...] [z] magazynu [...], na Biskupin do Ireny ${ }^{46}$. W garażu [...] zrobiliśmy magazyn papieru, [...] bo [...] przyszedł cały żuk, [...] samochód dostawczy cały [...] papieru. [...] Wiem, że [...] z Poznania przyszedł. No to syrenką przez całe miasto woziłem [ten papier]. [...] Wyciągnąłem siedzenia [...] z samochodu i przewoziłem. [...] Natomiast [...] powielacze chodziły do czasu, jak nie przeszliśmy, jako R ks, [...] na sitodruk. [...] Ja [już] nie wchodziłem w [tę] technikę sitodruku i zakończyłem wtedy bezpośrednio drukowanie. [...] Pamiętam komu przekazałem ten [jeden] powielacz [...], ale nie pamiętam, czy drugi też poszedł do nich. [...] Wcześniej, [nastąpiła] [...] wpadka, [doszło do] takiej [...] sytuacji [...], że padły drukarnie RKs-u. Zwinęli. To pamiętam, [że chyba przez] [...] miesiąc [...] maszyny chodziły mi non stop, bo musiałem [...] nadrobić [stracony czas]. [...] Dwie drukarnie wtedy padły. [...]

\section{Po stanie wojennym. Na celowniku sB. Próby zwolnienia z pracy}

Okazuje się, że sB-cja namierzyła [mnie] w [19]86 r. Po wpadce „Samarytanki" ${ }^{47}$. Bo ja drukowałem jeszcze [...] dla służby zdrowia „Samarytankę", bo [zgłosili] zapotrzebowanie. [...] [Wpadka nastąpiła poprzez] [...] „Walczącą" [...] w [19]86 r. i [...] „Samarytankę" - sB ich rozpracowywała ${ }^{48}$. I wiem, że [wtedy] namierzyli mnie, [...] z tym że nie ujawnili [tego] wcale. [...] nie wiem dlaczego [...] oni nie zaatakowali mnie, nie ujawnili, że namierzają. [...] Mam parę meldunków na mój temat, ale nie mam tych ostatnich, późniejszych. Nie ma, bo IPN [...] ponoć [ich nie posiada]. [...] W [19]86 r. zakończyłem druk - to jest [pod] koniec [19]86 r. chyba $[\ldots .$.$] ostatnie egzemplarze poleciały [\mathrm{w}][. .].[19] 87$, albo [19]86 r. [...] W każdym [...] razie [...], jak przeszli już na sitodruk, [to] ja przestałem drukować i zajmowałem się [już] tylko kolportażem. [...] [sв mogła już] widzieć, że ja już nie drukuję i odpuścili. [...] Pilnowałem bardzo tego, żeby [...] maszyny mi nie wpadły. [...] Z tym, że [moich] maszyn [...] nie namierzyli. Przez te całe lata do końca [...] nie zostały [...] namierzone. [...] Nie pamiętam ulicy, Berenta chyba, [na Karłowicach, koło wieży ciśnień], [...] dostałem informację, że [tam jest] [...] zagrożony powielacz, [...] o 7 rano wjechałem na lokal samochodem i zwinąłem powielacz, zabrałem, przeniosłem w inne miejsce. [...] [Jeśli dobrze] pamiętam tu na [...] [ul.] Stalową [...] do Zbyszka Szpryngla ${ }^{49}$. [...] On mnie ratował [wtedy], bo nie miałem gdzie

49
Prawdopodobnie chodzi o Irenę Pawlak, osobę bliżej nieznaną.

Pismo konspiracyjne wydawane we Wrocławiu w latach 1983-1986 przez „Solidarność” służby zdrowia. Zob.: S. Grzonkowski, Sekcja Służby Zdrowia NSzz „Solidarność” (Sekretariat Ochrony Zdrowia NSzZ „Solidarność”), [w:] Encyklopedia Solidarności. Opozycja w PRL 1976-1989, t. 2, red. G. Waligóra, Warszawa 2012 s. 400-402.

Solidarność Walcząca $w$ dokumentach..., s. 318-324.

Osoba bliżej nieznana. 
[przewieźć powielacza], [...] [a trzeba było szybko działać, na] gorąco. [...] Nie był [wcześniej] poinformowany, [że przyjadę z powielaczem]. [...] Były różne sytuacje. Ale jak trzeba było, to [potrafiłem wyrzucić] drukarza. Było tak, że [...] drukarza za nadużywanie alkoholu [...] musiałem zwolnić. [...] Zresztą to ciekawe, [...] to nawet jest ujęte w meldunku, że „Kuba” ${ }^{50}$ wyrzucił [drukarza]. Skąd [to wiedzieli], ciekaw jestem, któryś musiał sypnąć wtedy, chyba podejrzewam który, ale [...] nie chcę [już w to] wchodzić.

[...] Miałem prawdopodobnie [...] 190 [...] matryc, [które trzymałem] [...] w domu [...]. [W 1986 r.] miałem włamanie [do mieszkania], [w kwietniu lub maju]. [...] Oczywiście synowi klucz wyciągnęli ${ }^{51}$ [z szatni na sali gimnastycznej i otworzyli nim drzwi]. [...] Dużo, sporo miałem [matryc] [...], [trzymałem je] w domu u siebie. [...] . [I doszło do] [...] włamania [pozorowanego] [...] [na] złodziejskie. [...] [Zostało] ono [...] zgłoszone [...] na milicję [...] jako kradzież, włamanie. Ukradli [...] obrączki, pierścionki [...], mnóstwo książek [...], bo mieliśmy no cały zestaw Prousta, encyklopedie, atlasy. [...] Musieli co najmniej [...] ze dwie torby wynieść z domu i wyszli, zostawiając klucz w drzwiach. Wcześniej kiełbasę z lodówki psu dali [...]. Piesek był zadowolony, że ktoś przyszedł [...] i dał kiełbasę. [...] Takie były różne sytuacje. [...] A to ostatni meldunek ${ }^{52}$. [...] To nie wszystko prawdą jest. Bo ja już wtedy tam nie mieszkałem. To był stary adres. Samochód - już go [też] nie miałem [...]. To znaczy, [że] oni mieli o mnie stare informacje. Samochód miałem, jak w „Instalu” [pracowałem, a w] [...] [19]86 r. [zostałem zwolniony stamtąd]. [...]

\section{Pan został zwolniony?}

[...] Kilka razy byłem zwalniany, ponieważ próbowano mnie się pozbyć. Najpierw w białych rękawiczkach. [...] Chciano mi [...] sabotaż przypisać, więc później zrobiono mi niedopełnienie obowiązków. Wiem, że jedną sprawę wygrałem. Przywrócili mnie do pracy. Później [...] [mnie znów] zwolnili [...] - dwa miesiące [...] miałem zakaz wejścia na zakład. [...] Odwołałem [...] [się] do sądu i udało mi się wygrać. Przywrócili mnie z powrotem do pracy.

Ale to już było po stanie wojennym, czy w czasie [jego trwania]?

To było już po stanie wojennym [...] w [19]84 [lub] [19]85 r.

I rozumiem, że to za [...] pana działalność w „Solidarności”?

[...] Tak. Tak. [...] Z resztą [podam taki] przykład. [...] Naczelny dostał tele-

50 Pseudonim, pod którym działał w konspiracji Cz. Brokos (zob. Wstęp).

51 Czesław Brokos twierdzi, że włamania mogli dokonać funkcjonariusze sB, jednak nie ma na to dostatecznych dowodów. W trakcie rozmowy Cz. Brokos pokazywał kopie dotyczących go meldunków SB. 
fon: [...] „Gdzie jest Brokos, co robi Brokos?” - [padło] pytanie. [...] To [...] [działo się] przed [świętem] 1 Maja. [...] [Sytuację] relacjonował [...] mi [kolega, który był świadkiem tej rozmowy]. [...] [Naczelny odpowiedział:] „Nie pamiętam, nie wiem dokładnie, ale chyba pojechał do Mikoszewa w delegację". [...] Za moment [usłyszałem przez] radiowęzeł: „Brokos zgłosi się do sekretariatu”. W sekretariacie czekała delegacja do Mikoszewa. [...] [Chcieli] żebym pojechał tylko [...] na ośrodek wczasowy nasz, jako dysponent samochodu. [...] Jak wróciłem, pojechałem najpierw do Gdańska, [...] bo tam [...] [by1] strajk ostrzegawczy, na 3 [...] czy 1 Maja. [...] [W ten] sposób [naczelny] chronił mnie. [...] Cały czas [...] [mnie] śledzono.

Podobnie było przed manifestacją tą wrocławską ${ }^{53}$ [...] 31 sierpnia - co zginął Trajkowski ${ }^{54}$ w Lubinie, nasz pracownik. [...] Później [...] miałem [...] [jego] rodzinę w opiece, jeździłem [...] do żony i ona miała trójkę dzieci, o ile dobrze pamiętam. Żeśmy zbierali składki związkowe [...], wspomagałem ją finansowo [...] - jeździłem do niej [do Lubina]. [...] [Manifestacja] miała być [...] w poniedziałek. [...] [Dzień wcześniej] wyjechaliśmy [...] do teściów. Wracamy, [...] ja mówię do żony: „Jedź z dziećmi, ja jeszcze...", pojechałem [...] na kontakt [...] do swojego łącznika. [...] [Żona] zdążyła wejść z dziećmi do domu - [...], za moment łomot w drzwi - [weszło] pięciu w pełnym uzbrojeniu. Wpadli internować mnie. [...] Oczywiście przeszukiwali mieszkanie, balkon. [...] Nie ma. Wycofali się i [...] już drugi raz nie przyszli. [...] [Widocznie] mieli za zadanie zwinąć [mnie]. Nie zastali, to odpuścili, poszli drugich zwijać. [...] Ja [wróciłem później] wieczorem. [...] [Gdy dowiedziałem się, co się stało] to [...] w tył zwrot - już w domu nie nocowałem. Znów się ukryłem, [...] [wróciłem już po] manifestacji. [...] Prewencyjnie [chcieli aresztować] [...], później odpuścili. No, ale wpadli, [...] dwójka maluchów, [a] tu wpadają z karabinami [...] do mieszkania. No, [...] [to] było przeżycie. To opowiem [jeszcze inne] [...]. Stary i głupi [byłem] w zasadzie... Nie powinienem [był] tego zrobić. [...] Tylko że ja [nasze] dziecko uczyłem już od początku - no [...], ile on miał, wtedy chyba 4-5 lat, syn. [...] I my żeśmy przyszli razem z synem złożyć kwiaty pod tablicą ${ }^{55}$. [...] Udało mi się złożyć, mimo że [...] [była obstawiona przez] zomowców. [...] Przeszedłem na bezczelnego, udałem wariata. $\mathrm{Z}$ kwiatami wszedłem między nich,

53 Chodzi o tzw. bitwę wrocławską z 31 viII 1982 r., największą nielegalną manifestację podczas stanu wojennego w Polsce. Na ulice Wrocławia wyszło wówczas ok. 50 tys. osób, doszło do starć z milicją, zомо i wojskiem, w wyniku czego zmarły trzy osoby, zob.: W. Suleja, op. cit., s. 153-154. W 2016 r. powstał także film dokumentalny w reżyserii Beaty Januchty pt. Bitwa Wrocławska, traktujący o tym wydarzeniu.

54 Andrzej Trajkowski - jedna ze ofiar śmiertelnych manifestacji z 31 VIII 1982 r. w Lubinie, zastrzelony przez funkcjonariuszy zomo, strzelających do manifestującego tłumu. Więcej na temat zbrodni lubińskiej zob.: Ł. Kamiński, Drogi do wolności Zagłębia Miedziowego, Legnica 2007, s. 196-207.

55 Chodzi o tablicę upamiętniającą strajk z sierpnia 1980 r., która w pierwszą rocznicę strajku zawisła w pobliżu centrum strajkowego przy ul. Grabiszyńskiej 184 we Wrocławiu. 
na bezczelnego [...] [pod] tablicę [...]. Zwinęli mnie [...] [wraz] z synem. [...] A ja udałem głupka: „To co, nie wolno?” Przecież pod tablicami wolno składać kwiaty, nie? No to jest tablica upamiętniająca, ja chciałem upamiętnić. Złożyć kwiaty. [...] Udałem głupka i puścili [nas]. [...] Zwinęli [na chwilę] [...] do budy. [...] Widocznie [...] grałem dobrze [śmiech].

[...] A jeszcze jedno! [...] Przed [19]80 r. miałem wypadek przy pracy, [...] na kontrakcie w Czechach. [...] Jak ogłoszono stan wojenny, to mój dyrektor naczelny wymyślił, że pójdę na rentę i [tak] odejdę z zakładu. Ja najpierw trzymałem się rękoma i nogami, powiedziałem, że nie, nie odejdę [...] na żadną rentę i nie złożę wniosku. Ale [...] zobaczyłem [w] przepisach, że z chwilą kiedy ja przejdę na rentę, to zakład pracy ma obowiązek mnie zatrudnić [...] na innym stanowisku. [...] Więc zgodziłem [...] [się] na rentę. [...] Załatwiono mi szybko rentę, prawdopodobnie poprzez albo Urząd Bezpieczeństwa ${ }^{56}$, albo Komitet Wojewódzki [PZPR]. [...] Stanąłem na komisji i dostałem wtedy tą trzecią grupę. Rentę. I woła mnie naczelny i mówi: [...] „To pójdziesz na rentę". Ja mówię: „Nie, dyrektorze, to nie tak szybko. Proszę bardzo, tu są przepisy”. [...] Pięć minut ciszy. „Ale musisz pójść”. „Nie”, nie zgodziłem [się]. [...] Więc wtedy [...] dali mi wypowiedzenie, [...] [uzasadniając] że nie mają pracy dla mnie. [...] Odwołałem się. To wtedy jeszcze te komisje odwoławcze funkcjonowały. Odwołałem się i doprowadziłem [do tego] [...], że musieli się zgodzić [...] na ugodę. I z powrotem mnie przyjąć. [...] Jakiś [...] czas [...] [miałem] spokój, [...] [ale robili] różne podchody. [...] A ja byłem zawsze, całe życie, człowiekiem walki, więc uwielbiałem takie podchody. [...] Później drugi raz mnie zwolnili, znów wygrałem. [...] [Potem] chciano mi przypisać sabotaż, w końcu zrobiono mi niedopełnienie obowiązków i zwolniono mnie - chyba dyscyplinarnie. [...] Dwa miesiące mnie nie dopuszczono do pracy i [...] zakłady robiliśmy [...], że jak się odwołam, to wygram sprawę w sądzie. [...] Umiejętnie poprowadziłem tą sprawę i wygrałem. [...] I dopiero później, to było już [...] [19]84, albo [19]85 r. W [19]84 r. chyba rozmawiałem [...] [z] naczelnym [i] mówię [mu]: „Dyrektorze, przecież, kurczę, znacie mnie..., że ja [...] w czasie walki [...] nie odejdę, no bo, kurczę, z pola walki to ja nie odejdę, jakbyście, kurczę, [za mną] nie chodzili, nie truli, [...] nie próbowali, dali mi spokój, to może by mi się znudziło [i] bym odszedł [...]".

A! Ciekawa sytuacja: otarłem się o człowieka WSW ${ }^{57}$. [...] I to na samym początku. U niego drukowałem. [...] Chciał się dostać [...] do Radia „Solidarność"58

56 Wówczas Służbę Bezpieczeństwa.

57 Wojskowa Służba Wewnętrzna - organizacja zajmująca się w latach 1957-199o kontrwywiadem wojskowym na terenie Polski.

58 Radio związane z NSzz „Solidarność”. Nadawało w konspiracji w latach 1982-1989 z prowizorycznych rozgłośni w wielu miastach w Polsce, w tym we Wrocławiu. Audycje były zazwyczaj krótkie i trafiały do bardzo ograniczonej grupy odbiorców. Szerzej na ten temat zob.: P. Pietkun, Tu Radio Solidarność... Przyczynek do historii podziemnego Radia Solidarność 1982-1989, Warszawa 2018. 
[...] i szukał kontaktów. [...] To na początku było, [...] w [19]82 r., na wiosnę. [...] To było, [...] na Kuźnikach ${ }^{59}$, [...] po Różance ${ }^{60}$ chyba. [...] Właściwie to nie był aktywnym [...] agentem WSW. Bo gdyby był aktywny, gdyby chciał, to by na samym początku mógł mnie rozpracować. [...] Dowiedziałem [się o tym] [...] parę lat temu. No powiedzmy już po [19]89 r., że on był w [...] WSW.

\section{Zaprzestanie konspiracyjnego drukowania. Stosunek do okrągłego stołu}

Później, [po] [...] zakończeniu [drukowania], [...] przekazałem [...] powielacz. [...] Uznaliśmy, że nie będziemy [...] [dłużej drukować z „Z Dnia na Dzień”, gdyż] coraz [...] gorszy druk szedł i szkoda [było] papieru. [...] Lepszą [techniką] był [...] sitodruk, [zdecydowanie mniej papieru na to szło]. [...] [Ale, aby] powielacze [nie stały] nieużyteczne, [przekazaliśmy je dalej]. [...] [Mogły się przydać] komuś, kto chce jeszcze drukować [...] [np.] zakładowe ulotki. [...] [Jeden powielacz] poszedł do Grzegorza Czyża ${ }^{61}$. [...] Spotkałem [się z nim] na Gajowickiej [...], na mieszkaniu. [...] Oni [robili] [...] coś tam ze spółdzielczością. [...] Chcieli drukować, to wtedy im oddałem. Nie pamiętam, gdzie poszedł ten drugi powielacz. [...] [Przekazałem też] maszynę do pisania. [...] Zależało [mi wtedy], [...] żeby [ktoś jeszcze na tym sprzęcie] skorzystał. [...] Nie pamiętam w tej chwili, gdzie ta maszyna [...] poszła. [...] [Należy jeszcze] wspomnieć [...] Wadowskich. [...] On jest świętej pamięci - Zbyszek Wadowski, ale Wiesia jeszcze żyje ${ }^{62}$. [...] U nich [w mieszkaniu] [...] druk robiłem. [...] Wtedy była to [ulica] 9 Maja [...], teraz jest 8 Maja. [...] To było na Sępolnie, [...] [a] na Biskupinie miałem Irenkę ${ }^{63}$ [z matrycami]. [Od niej] [...] przenosiłem matrycę [...] na tego 8 Maja. [...]. To też oni obydwoje ${ }^{64} \mathrm{w}$ „Instalu" [pracowali i] byli [...] w komitecie strajkowym. [...] Później, [po skończeniu z drukowaniem,] zajmowałem się jeszcze kolportażem. [Był] to taki bardziej nadzór, [...] tu trzeba [coś] załatwić, tam przewieźć. [...] Później, [...] nie pamiętam, [w 19] 88 czy [19]89 r., [...] [odbyło się] zebranie w klubie budowlanych ${ }^{65}$ [...], to było już [podczas] okrągłego stołu, to chyba [19]89 r. [...] [To było spotkanie z]

59 Wrocławskie osiedle zlokalizowane w zachodniej części miasta.

60 Wrocławskie osiedle zlokalizowane w północnej części miasta.

61 Grzegorz Czyż - działacz opozycji. Redagował m.in. „AUT” (pismo wydawane przez pracowników Centrum Naukowo-Produkcyjnego Automatyki Energetycznej) oraz współpracował z redaktorami „Chcąc nie chcąc” (pismo V Liceum Ogólnokształcącego we Wrocławiu), zob.: Sz. Rudka, op. cit., s. 301, 386.

62 Wiesława i Zbigniew Gajkowie byli pracownikami „Instalu” oraz należeli do tamtejszej Komisji Zakładowej „Solidarności”.

63 Osoba bliżej nieznana.

64 Zbigniew i Wiesława Wadowscy.

65 Chodzi o ówczesny Dom Kultury Budowlanych przy ul. Braniborskiej we Wrocławiu. 
Frasyniukiem $^{66}$, z Baśką Labudową ${ }^{67}$, [...] oficjalne, już za zezwoleniem władz. [...] I ja wtedy, szczerze mówiąc, wściekłem się i podjąłem decyzję: koniec.

\section{A czemu Pan się wściekt?}

Bo mnie [...] śmierdziało układem. [...] Byłem od początku w „Solidarności”. Widziałem na bieżąco różne rozgrywki. [...] [Dużą rolę grały] ambicje poszczególnych ludzi, wojny, oskarżenia, a ten korowiec ${ }^{68}$, a to, a tamto. [...]. Byłem delegatem na zjazd wrocławski. Obserwowałem, jak szły różne akcje w stosunku do Piórkowskiego ${ }^{69}$, pierwszego przewodniczącego. Byłem obserwatorem i byłem na zjeździe, [na którym] [...] wybrano Frasyniuka [na przewodniczącego] ${ }^{70}$. Może ja nigdy nie byłem [...] za nim. Dlatego [nadal patrzę na niego] [...] krytycznie trochę, ale starałem się w miarę obiektywnie i powiem tylko tyle [z] mojej obserwacji: gdzieś tam już po północy, jak były wybory, Frasyniuk miał przeciwników. Głównie [...] [z] terenu Legnicy, Wałbrzycha. [...] [Ale trwała] akcja promowania Władka. Grupa osób promowała w kuluarach, [...] zresztą mnie [również] [...] agitowano na [...] różne sposoby [...]. Jak ktoś z grupy przeciwnej szedł do mikrofonu, chciał zabrać głos przeciwko Władkowi, to było wytupywanie, hałas i [...] nie dopuszczano do głosu. [...] [Powstawał] szum [...], rwetes, krzyki. Wychodził Karol [...] Modzelewski ${ }^{71}$ [...] i [...] swoim spokojnym głosem [...] potrafił zapanować [nad delegatami]. [...] Inna sprawa, że manipulując trochę. Ale fakt, trzeba było mu [...]

66 Władysław Frasyniuk (ur. 1954 r.) - w czasach PR L wrocławski działacz opozycji. Od 4 III 1981 r. przewodniczący wrocławskiego Międzyzakładowego Komitetu Założycielskiego, a od 30 vi 1980 r. Zarządu Regionu Dolny Śląsk NSzz „Solidarność”. Po wprowadzeniu stanu wojennego stanął na czele R KS NSzz „Solidarność” Dolny Śląsk i pełnił funkcję przewodniczącego do czasu aresztowania 5 x 1982 r. Zob.: A. Borowski, M. Łątkowska, Władysław Frasyniuk, [w:] Encyklopedia „Solidarności”: opozycja w PRL 1976-1989, red. M. Łątkowska, t. 1, Warszawa-Katowice 2010, s. 115-116.

67 Barbara Labuda (ur. 1946 r.) - w czasach PRL wrocławska działaczka opozycyjna. Współpracowała z Komitetem Obrony Robotników, wspierała strajk solidarnościowy w zajezdni nr viI, zob.: A. Borowski, Barbara Labuda https://encysol.pl/es/encyklopedia/ biogramy/17204,Labuda-Barbara-Lidia.html?search=6380478 (dostęp: 30 xII 2020 r.).

68 Potoczne określenie działacza Komitetu Obrony Robotników.

69 Jerzy Piórkowski (ur. 1941 r.) - kierowca M PK, przywódca strajku solidarnościowego w zajezdni nr viI we Wrocławiu. Pierwszy przewodniczący wrocławskiego MKz. Zob.: K. Dworaczek, Jerzy Piórkowski, [w:] Encyklopedia „Solidarności”: opozycja w PRL 1976-1989, red. J. Olaszek, t. 4, Warszawa 2020, s. 344.

70 Do zmiany na stanowisku przewodniczącego wrocławskiego $\mathrm{M} \mathrm{Kz}$ doszło 4 III $1981 \mathrm{r}$.

71 Karol Modzelewski (1937-2019) - historyk, opozycjonista w czasach PR L. Był wrocławskim delegatem na ogólnopolską debatę przedstawicieli M Kz-ów 17 IX 1980 r. Jeden z pomysłodawców nazwy dla powstającego wówczas związku zawodowego. Zob.: A. Borowski, M. Łątkowska, Karol Modzelewski, [w:] Encyklopedia „Solidarności”: opozycja w PRL 1976-1989, red. M. Łątkowska, t. 1, Warszawa-Katowice 2010 s. 286-287; K. Modzelewski, Zajeździmy kobyłę historii. Wyznania poobijanego jeźdźca, Warszawa 2013. 
przyznać, że potrafił zapanować, uspokoić salę. [...] Ja odnosiłem wrażenie, że [on] był za Frasyniukiem. [...] Za Frasyniukiem był jeszcze [...] Maciek Zięba ${ }^{72}$, późniejszy dominikanin. [...] On był też delegatem [i] [...] przekonywał mnie [...] do Frasyniuka.

\section{[...] Piórkowski sam zrezygnował z bycia przewodniczącym?}

Został przymuszony, zastraszony [...] ponoć przez s в. [...] I teoretycznie wycofał się, ale jest to nieprawdą, żeby tak dobrowolnie się wycofał, nie. Przymuszono go do wycofania się. [...] Frasyniuk był do ulepienia. [...] Z Frasyniuka tworzono dopiero [przywódcę]. Frasyniuk jeszcze był młody, [pracował] jako kierowca [...], trochę może [był], powiedzmy, bardziej rozgarnięty, po technikum [...] był. [...] Frasyniuk [był] [...] taki trochę hurra bura [...], potrafił [...] się wypowiedzieć [...], w zasadzie [...] jego [pierwszą] funkcją [...] był rzecznik [...] prasowy [w czasie] strajku [w 1980 r.]. [...] Był kandydatem [...] do uformowania [na przywódcę] [...]. [Była] grupa, która chciała [go] uformować. No i formowali. No Baśka Labuda między innymi. On był pod dużym wpływem Baśki Labudowej. A Baśka Labudowa była [...] komunistką. [...] Ona zafascynowana była rewolucją francuską: w [19]68 r. była we Francji, w czasie tej rewolucji ${ }^{73}$. [...]

No właśnie ciekawa sprawa, na ile członkowie, czy chociażby ci delegaci właśnie, na ile oni byli faktycznie takimi antykomunistami, chcieli obalić ten system, a na ile...

Nie, nie, to, to nie. Nie było to tak, że... Ja powiem tak: [połowa] kadry [...] nie była świadoma tego, że chciałaby obalić ten komunizm, niektórzy chcieli ulepszać. [...] Nie przychodziło [im] na myśl, że można obalić. Ja pamiętam nasze dyskusje, w czasie stanu wojennego, jak myśmy się zbierali i dyskutowaliśmy. Właśnie jeszcze u „Anzelma” tak zwanego - Gliwy Józia. On pseudonim miał „Anzelm”. To u „Anzelma” żeśmy dyskutowali. Z zakładów pracy tam, z „Polaru”74 przychodzili łącznicy, z „Chemitexu”75 - z tych zakładów, tam po ulotki, nie, i ja czasami

72 Maciej Zięba (1954-2020) - w czasach PRL wrocławski działacz opozycji, później dominikanin. W czasie strajku solidarnościowego we Wrocławiu w sierpniu 1980 r. był łącznikiem pomiędzy Międzyzakładowym Komitetem Strajkowym w zajezdni autobusowej nr vII a arcybiskupem wrocławskim. Zob.: B. Szaynok, Maciej Zięba, [w:] Encyklopedia „Solidarnośi": opozycja w PRL 1976-1989, red. M. Łątkowska, t. 1, Warszawa-Katowice 2010 s. 510.

73 Chodzi o protesty społeczne we Francji pomiędzy majem a lipcem $1968 \mathrm{r}$.

74 Chodzi o Zakłady Mechaniczne „Polar” zlokalizowane przy ul. Bora-Komorowskiego 6 (wówczas ul. Warskiego 6) we Wrocławiu. Zob.: http://dolnoslaskosc.pl/zaklady-metalowe-polar,1689.html (dostęp: 20 I 2021 r.).

75 Chodzi o nieistniejące już Wrocławskie Zakłady Włókien Chemicznych „Chemitex” zlokalizowane przy ul. Kwidzyńskiej 6 we Wrocławiu, specjalizujące się w produkcji m.in. wiskozy. Zob.: http://dolnoslaskosc.pl/wroclawskie-zaklady-wlokien-sztucznych-chemitex-,1671.html (dostęp: 20 I 2021 r.). 
się spotykałem tam u nich [...] i żeśmy dyskutowali i obliczaliśmy, że nim komuna upadnie, to gdzieś tam jeszcze z 50 lat. [...] To był rok [19]82, [19]83. [...] [Nie liczyliśmy na to, że] komuna upadnie w ciągu tego dziesięciolecia [...]. Liczyliśmy, że to 30-50 lat będzie się trzymać, bo ponieważ jeszcze Związek Sowiecki nie popuści, utrzyma się... To także na długą walkę gdzieś się żeśmy ustawiali.

Czyli był bardziej kierunek na polepszenie tego systemu, polepszenie swojego bytu w tym systemie?

Tak, na rozluźnienie [...]. Wtedy to człowiek młody [był], 30 lat miałem [...]. Zachłystywałem się trochę tą wolnością [...], ale później już zdawałem sobie sprawę, że to lekko nie będzie, [...] że komuna nie popuści. [...] Chociaż jestem przeciwny temu, ale także twierdziłem, że jeżeli [...] nie przejmie komuna systemu gospodarczego, to nie uwłaszczy się. [...] Jeżeli chcemy doprowadzić, żeby to było bez rozlewu krwi, to trzeba dać im coś - profity. Bo jak nie będą mieli profitów, to nie popuszczą. [...] To będzie rozlew krwi. No bo od koryta odciąć to jest najgorsze, nie?

[...] W mojej ocenie okrągły stół [...] byłby sukcesem. Byłby. On mógł być sukcesem. On się nie stał, nie stał sukcesem, on jest tragedią dla nas - okrągły stół. Ponieważ za okrągłym stołem nie poszło nic. [...]. Komuna została okrągłym stołem utrwalona. [...] My żeśmy jako ostatni z tych wszystkich narodów, cokolwiek zmieniali w tych wyborach demokratycznych. Podchodziliśmy [...] jako ostatni z narodów ${ }^{76}$. Nawet ten sejm... No, nie... System gospodarczy, też... [...] Przejmowanie gospodarki. Oddanie raz, że gospodarki. No przez niszczenie zakładów to [się] odbyło... Druga sprawa - w ogóle [dla] [...] mnie [...] [żeby przejść] z komunizmu [...] do rynkowej gospodarki, trzeba cudów. [...] Ale to, co zrobił Balcerowicz ${ }^{77}$, no to... [...] Doprowadzane były zakłady do upadku celowo, żeby można było przejąć. Przejąć za złotówkę.

\section{Część II}

[...] Skąd mieliście wiadomości o strajku na Wybrzeżu? Jak [...] [dowiedzieliście się] że [...] Wybrzeże i [...] inne części Polski strajkują? Jak te informacje dotarty do was? O ile ja dobrze pamiętam, to ja w tym czasie słuchałem Wolnej Europy ${ }^{78}$. [...]

76 Chodzi tutaj o chronologię wyborów demokratycznych w bloku państw komunistycznych.

77 Leszek Balcerowicz (ur. 1947 r.) - polityk i ekonomista. Główny pomysłodawca i realizator transformacji gospodarczej w Polsce w latach 1990-1991. Więcej na temat transformacji gospodarczej zob.: M. Bałtowski, M. Miszewski, Transformacja gospodarcza w Polsce, Warszawa 2019.

78 Chodzi o Radio Wolna Europa. 
[...] Wspominat pan jeszcze o przemówieniu [...] do pracowników [przed rozpoczęciem strajku]...

[...] Przekonywałem, że [...] musimy [działać] solidarnościowo. [...] [Mówiłem o] zakłamaniu komunistycznym, [...] że przeciwko temu musimy [wystąpić]. [...] Mówiłem [także] o godności naszej [...] i o solidarności. [...] Że musimy [strajkować], tym bardziej, że u nas już jeden wydział stanął, [...] tak zwane warsztaty, gdzie [...] produkowano wentylacje, [...] blacharnia, [...] wyciskarki, [...] hala produkcyjna [stanęła] [...] dzień wcześniej. Na drugi dzień, od rana od godziny ósmej, [...] żeśmy biegali [...] po pokojach i zebranie [zorganizowaliśmy] i od rana od razu żeśmy stanęli. [...]

[Byty] jakieś głosy sprzeciwu?

A były. Były, były. [...] Był [taki] stary sekretarz partii ${ }^{79}$, [...] świętej pamięci już. [...] Dyskutowałem [...] [z nim i] nawet mnie próbował odwieść [...] od zakładania później „Solidarności”, już po strajkach. [...] Jak ja [...] angażowałem się w „Solidarność”, no to on mnie straszył, stary był Sybirak, gdzieś tam ze wschodu był [...] i, fakt, [...] być może znał tę komunę z tej strony, gdzie morderstwa, nie morderstwa, że mnie zlikwidują, że mogą mnie zamordować, że on zna [...] takie argumenty, [...] straszenie i tak dalej. [...] Były wojskowy, [...] pamiętam, pan Janik $^{80},[\ldots]$ też $[. .$.$] zabierał głos [...] przeciw mnie. [...] No i była [...] [dyskusja,$ kto] do komitetu strajkowego [...] od nas z dyrekcji. [...] No [...] to Czesiek! [...] [Tak wskazali] ludzie. [...] Powiedziałem: „okej!". [...] I tak wszedłem [do komitetu strajkowego] [...], ale jak już wchodzę, no to [...], fakt, że [...] zawsze [aby] [...] od razu zarządzać. [...] [śmiech]. No i tak zostałem trochę właściwie przywódcą tego strajku. [...] Szczerze mówiąc emocjonalnie się zaangażowałem. [...] To były u mnie tak [wielkie] emocje, że [...] chyba do tej pory gdzieś tam mam. [...]

A jak pan zwoływał [...] to zebranie, to był pan przekonany, że się uda, że się uda zrobićten strajk?

Tak. Ponieważ już stał warsztat. [Choć] szczerze mówiąc, to [...] inna specyfika zawsze [panuje wśród] [...] dyrekcji. [...] Ponieważ tu zależność [...] od szefa [...] [jest silniejsza, istnieje większy strach wśród pracowników], no bo stołek wytrącić zawsze łatwiej jest, niż łopatę zabrać komu [...] z ręki. [...] Fizyczny [pracownik] się nie boi tak, natomiast stołek wytrącić można szybciej, [...] [ale] byłem [dobrze] zorientowany, bo już żeśmy rozmawiali dzień wcześniej [na temat strajku]. [...] Rozmawiałem z kilkoma ludźmi [wcześniej i wiedziałem], że będą chętni. [...] 
[Strajk rozpocząt się] 27 sierpnia, tak? [...].

Tak, bo 28 zaczęła [strajkować] dyrekcja, cały zakład. 28. [...]

27 [staną] ten pierwszy wydziat, tak?

Tak, to był Wydział Pierwszy, a 28 to już poszła [cała reszta]. Już telefony na oddziały, [...] że zakład stoi - strajk.

\section{A delegat zostat wystany 28?}

27.

[...] Zapytam jeszcze o [...] atmosferę tego [...] strajku. [...] Obawialiście się [interwencji]? [...]

Tak, [...] [porozstawialiśmy] warty przy bramach na zakładzie [...], pilnowaliśmy. [...] Były obawy, że [będzie] interwencja. [...] [Zorganizowaliśmy także] całonocne czuwanie. [...] W tym czasie [było nas] sporo, [...] [na noc zostawało ok.] 30-40 osób na zakładzie. [...] [Przejęliśmy] ten rozległy [...] teren: [...] bramy, [...] stróźówkę, wartownie [...], [obsadziliśmy go] ludźmi [...] z komitetu [strajkowego]. [...] [Głównie] urzędowaliśmy w świetlicy, [...] mieliśmy [...] śpiwory [...], kucharki [nawet] stołówkę nam [udostępniły, klucze nam zostawiły do] [...] bufetu. [...] Przygotowywaliśmy jedzenie. [...] To była [...] solidarność [...] nie z nazwy, tylko właśnie międzyludzka [...], taka emocjonalna. [...] My żeśmy nie zgłaszali swoich postulatów [...], nawet od dyrekcji. [...]. My [...] solidaryzowaliśmy się [...] z Wybrzeżem i [...] popieraliśmy ich postulaty. [...] Później, po strajku, [...] stawialiśmy postulaty. [...] Pamiętam, [że] jako [...] przedstawiciel komisji [...] [jeździłem] do Zjednoczenia ${ }^{81}$ [...] na negocjacje, [w sprawie] [...] zmiany dyrektora u nas. [...] Żądaliśmy [...] odejścia dyrektora, to był dawny przewodniczący miejskiej rady narodowej [...], [należał] do nomenklatury. [...] To nie był fachowiec, [...] więc żądaliśmy [jego odejścia]. [...] Pamiętam, [że] wtedy [...] do dyrektora zjednoczenia [...] jeździłem [...] w tej sprawie, ale to były postulaty późniejsze. Natomiast strajkowe to były tylko postulaty [...] Wybrzeża.

[...] Na co liczyliście po tych [strajkach], [...] jakie byty [dalsze] plany?

Dla mnie [...] [najważniejsze] [...] były [...] właśnie [...] związki zawodowe. [...] Bardzo zaangażowałem [się w ich działalnośćc. [...]

81 Chodzi o Wrocławskie Zjednoczenie Budownictwa. Funkcjonowało ono w latach 1961-1982 i zrzeszało przedsiębiorstwa państwowe na terenie województwa wrocławskiego, a od 1975 r. również województwa opolskiego. W latach 1980-1981 działa przy w z в Komisja Zakładowa Nszz „Solidarność”. 
Czyli przez tą działalność związkowq chcieliście jakby wpływać na ten system, tak na pewną zmianę?

[Chcieliśmy] wpływać na system poprzez [...] dokonywanie swoich własnych, rzeczywistych wyborów, [...] przynajmniej na poziomie zakładu. [...] To wtedy [pojawiły się] [...] pomysły rad pracowniczych. [...] [Mieliśmy także nadzieję], że poprzez związki [zawodowe] będziemy potrafili [...] w jakiś sposób kontrolować [sytuację], że partia ${ }^{82}$ nam [...] nie będzie stawiała [warunków], narzucała [swojego zdania], tylko że my sami będziemy potrafili [działać]. [...]

\section{Czyli tak oddolnie?}

Oddolnie, że [...] sami będziemy potrafili kontrolować [...] [sytuację w „Instalu"] poprzez [...] rady pracownicze. [...] Zresztą takie [...] [też podjęliśmy] próby. $[\ldots]$

Mówit pan [także], że spodziewano się stanu wojennego. [...] Skąd były takie [informacje]? [...]

Robiłem [...] różne ulotki, które puszczaliśmy z Rks-u. [...]. [Wśród nich] były instrukcje, jak zachować się w razie wprowadzenia stanu wojennego. Były podejmowane uchwały na wypadek stanu wyjątkowego, [...] [bo] my żeśmy mówili o stanie wyjątkowym. [...] Już przy [wydarzeniach] bydgoskich ${ }^{83}$ [...] rozważa[liśmy] [zaostrzenie sytuacji]. [...] [Nastąpiła wtedy w naszych szeregach] koncentracja. [...] A później, w październiku [1981 r.], [...] przed zjazdem „Solidarności" ${ }^{\text {, }}$, [...] zrobiłem zebranie załogi i podjęliśmy uchwałę o strajku. [...] Ogłosiliśmy, że: „W przypadku stanu wyjątkowego załoga podejmuje strajk". [Wobec tego] w poniedziałek rano ${ }^{85}$ zebrałem załogę, [...] [aby] tylko ogłosić im, [...] że przystępujemy do strajku. Natomiast [...] [pojawiły się] głosy [sprzeciwu], [...] między innymi przewodniczącego Władka ${ }^{86}$, dyrektora ${ }^{87} \mathrm{i}$ [...] [jednej] babki ${ }^{88} \mathrm{z}$ komisji zakładowej, [...]

82 Chodzi o Polską Zjednoczoną Partię Robotniczą.

83 Chodzi o tzw. prowokację bydgoską z 19 III 1981 r., zob.: K. Osiński, P. Rybarczyk, Kryzys bydgoski 1981. Przyczyny, przebieg, konsekwencje. Tom I. Monografia, Bydgoszcz-Gdańsk-Warszawa 2013.

84 Chodzi o I Krajowy Zjazd Delegatów nszz „Solidarność” w dniach 5-10 Ix i 26 IX-7 X 1981 r., zob.: I Krajowy Zjazd Delegatów NSzZ „Solidarnośc”": stenogramy, t. 1: I tura, red. G. Majchrzak, J.M. Owsiński, Warszawa 2011; I Krajowy Zjazd Delegatów NSzZ „Solidarność”: stenogramy, t. 2 cz. 1: II tura, red. G. Majchrzak, J.M. Owsiński, Warszawa 2013; I Krajowy Zjazd Delegatów NSzz „Solidarność”: stenogramy, t. 2, cz. 2: II tura, red. G. Majchrzak, J.M. Owsiński, Warszawa 2013.

85 Tj. 14 XII 1981 r., dzień po wprowadzeniu stanu wojennego.

86 Władysław Puzanowski.

87 Osoba bliżej nieznana.

88 Osoba bliżej nieznana. 
nie pamiętam jej nazwiska. [...] Przekonywałem [ich], że my już decyzję podjęliśmy [...] [i] ona jest wiążąca. [...] No, ale [przegłosowane zostało], [...] że wyślemy łącznika [...] do Pafawagu ${ }^{89}$, zobaczyć [...], co się dzieje w tych [większych] zakładach. [...] [Jeśli one] stoją, [...] to my też staniemy, ale żebyśmy [...] [na razie się powstrzymali i] nie ogłaszali strajku. [...] Chłopaki zarządzili, żebym [...] nie szedł do dyrekcji, tylko [...] [od razu] na tak zwaną halę produkcyjną, do pracowników. [...] [Wtedy] już przyszły [...] informacje, że [...] [do pacyfikacji zakładów pracy zostały użyte] czołgi. [...] Mieliśmy zrobić spotkanie o godzinie 13, [ale zrezygnowaliśmy z tego]. [...] [Zdecydowaliśmy,] że [...] nie ma sensu robić u nas [strajku, bo] zakład [był] za bardzo otwarty. [...] Raz, [że] nie ma [...] jak [...] [się bronić], a dwa [...], że [...] nie odpuszczą [nam], bo [zakład znajdował się] [...] przy samym CPN-ie i [będą chcieli go] [...] zabezpieczyć. [...] Było wiadomo, że od razu [wyślą] wojsko. [...] Po południu przeniosłem się z zakładu na Biskupin, i tam, w pobliżu [...] zakładu [ukrywałem się] u [...] Irenki Pawlak ${ }^{90}$. [...]

[...] [W czasie stanu wojennego] wszedt pan w [drukowanie]. [...] Dlaczego akurat poligrafia? Dlaczego drukarnia?

[...] Dostałem pytanie, czy bym nie chciał drukować. [...] [Zaproponował mi to] Kornel [Morawiecki] poprzez [...] Leszka Bielaka. [...] [Nigdy wcześniej] nie drukowałem, ale wszystko jest do nauczenia. [...]

\section{Gdzie pan drukowat?}

Pierwszy [mój „lokal”] było właśnie na Różance.

Ale to, to nie było pana mieszkanie? [...]

Tak, to było na „lokalach". [...] U siebie w domu nie drukowałem. Miewałem [u siebie] różne rzeczy: [...] papier [...], matryce, [...] natomiast [drukowałem gdzie indziej]. [...] Później drukowałem [...] tak jakby u siebie, [bo miałem] „lokal” [...] u [swojej] dziewczyny. [...] Potrzebowałem [nowy] „lokal”, bo właśnie musiałem się przenieść z Kuźnik i to był [...] 24/25 czerwca [1982 r.], [...] jakoś tak początek wakacji, Małgosi ${ }^{91}$ syn pojechał na [te] wakacje. Miała więc wolne mieszkanie, była [...] koleżanką mojego [...] łącznika, [...] „Arka", [to zostałem poinformowany], że [...] mamy mieszkanie, [...] będzie można drukować. [...] [Odbywało się to w ten sposób,] że [...] Baśka Sarapuk miała klucze do tego mieszkania i [...] umawiałem

89 Pafawag był o tyle istotny, że w dniach 14-15 grudnia przebywali na jego terenie przedstawiciele uformowanego dzień wcześniej R Ks-u, m.in. P. Bednarz, W. Frasyniuk i Józef Pinior. Trudno jednak stwierdzić, czy pracownicy „Instalu” wiedzieli wówczas o tym. Zob.: W. Suleja, op. cit., s. 137-138. Osoba bliżej nieznana.

91 Chodzi o późniejszą żonę Czesława Brokosa. 
[się z nią na konkretną] godzinę. [...] Baśka otwierała mi [...] i drukowaliśmy. [...] Gospodyni [wracała] dopiero, [jak skończyliśmy]. [...] Mieliśmy się wcale nie widzieć. [...] Drukowaliśmy zawsze w dwójkę. Na ramce [tak] trzeba było drukować. Ja [...] [przejeżdżałem] wałkiem, a przeważnie dziewczyna odbierała kartki. [...]

A jakie to były nakłady?

[...] Różne, no było i 2-3 tysiące.

To ile czasu [zajmowało wydrukowanie] na ramce [...] dwóch tysięcy [egzemplarzy]? [...]

Sporo. [...] Dwustronne, [...] [to] cztery tysiące razy trzeba było ramkę podnieść i wałkiem przejechać. [...] W ten sposób [się to odbywało]. I tak cały czas. [...] Trzask, ramka do góry. Ona odebrała. Ramka na dół. I wałkiem znów. I co jakiś czas szkło. [...]. Na szybie [znajdowała się] farba drukarska. I się wałkiem jechało po farbie, po szybie, bo [...] [była] gładka. [...] Rozprowadzało się farbę na wałku i przenosiło się ją na ramkę. Ramkę [tworzyło się z różnych przedmiotów], [...] nawet robiłem tak, że naciągałem prześcieradło, płótno, bo ramkę się obciągało płótnem, na to mocowało się matrycę, [...] farba i jechało się. [...] Później, było więcej [drukowania], bo jak robiłem i „Walczącą" i „Z dnia na dzień”, [...] to trzeba było podwójnie [...] [wszystko] zrobić.

No właśnie, bo [...] [dodatkowo] pracowat Pan, tak? [...] Więc [...] po pracy umawiat się Pan z kimś o konkretnej godzinie w lokalu [...] i później do pracy na drugi dzień?

I później do pracy. [...] Prowadziłem wtedy bardzo intensywne życie. Sypiałem bardzo mało, [...] ale [...] człowieka trzymały emocje, [...] te pozytywne emocje. [...] Na początku [...] trzy razy w tygodniu, co drugi dzień żeśmy wydawali. [...] [Te gazetki] były dwukartkowe przecież, no to, żeby jeden numer [...] [wydać], to cztery razy trzeba było wałkiem przejechać. [...] [Tak więc, aby] zrobić tysiąc [...] [egzemplarzy], to trzeba [było] cztery tysiące razy wałkiem przejechać. [...] Nie trzeba było dużo, bo gdyby [...] [milicja] popatrzyła [...] tylko - to kurczę zawsze było gdzieś [dużo] farby, bo ręce były zawsze po łokcie w farbie różnej. [...] A różne żeśmy kombinowali. Jak nie było farby, to jakąś czerwoną farbę żeśmy [używali]. Miałem [...] gazetki na czerwono wydrukowane też. [...] W zwykłych słoikach miałem różną farbę drukarską. [...] Jedną gorszą, drugą lepszą. Jedna się mazała, druga nie. [...] Widać [to po] niektórych drukach. [...] To ci się mazała, [to] nie schła... [...] Kiedyś miałem taką przygodę, że moja późniejsza małżonka, jak pisała matrycę, to siedziała [...] obok grzejnika [...] i rurki. [...] I [wzięła] napisaną matrycę, [i] odwiesiła na tą rurkę. [...] A grzejnik grzał, rurka ciepła. [...] I ja wziąłem matrycę i założyłem na bęben [...] [i] matryca się rozeszła. [...] [Spieszyłem się, aby] jeszcze raz pisać matrycę na nowo. [...] Przygody różne były [...] takie... 


\section{[...] [Bywało też] niebezpiecznie?}

[Raz] przekonany byłem, że wtedy miałem ogon. [...] Wtedy na ramce jeszcze robiłem chyba, [...] u takiej plastyczki ${ }^{92},[. .$.$] na Jedności [Narodowej] chyba. I pa-$ miętam podejrzane zauważyłem ruchy za sobą. [...] Kontrolowałem, żeby [...] zgubić ogon [...] i sprawdzałem, czy rzeczywiście [go mam]. Przez podwórka lecę, pamiętam, że [na ul.] Sienkiewicza, dolatuję przez bramę przelotową, a za moment facet za mną [...]. No, mówię: „Czesiek, to już dzisiaj na lokal nie idziesz, na ramkę". [...] [Byłem] niepewny, [...] czy nie przyprowadzę kogoś. [...] No, ale [...]. Do [...] [19]86 r. tyle [...] tych mieszkań [...] było, [...] mnie jakoś nigdy [...] nie namierzyli. [Za] to jestem $\mathrm{z}$ siebie [dumny], że przeze mnie [...] nikt nie wpadł. 


\section{Bibliografia}

I Krajowy Zjazd Delegatów NSzz „Solidarność: stenogramy, t. 1: I tura, red. G. Majchrzak, J.M. Owsiński, Warszawa 2011.

I Krajowy Zjazd Delegatów NSzz „Solidarność: stenogramy, t. 2, cz. 1: II tura, red. G. Majchrzak, J.M. Owsiński, Warszawa 2013.

I Krajowy Zjazd Delegatów NSzz „Solidarność”: stenogramy, t. 2, cz. 2: II tura, red. G. Majchrzak, J.M. Owsiński, Warszawa 2013.

Adamski A., Kornel. Z przewodniczącym Solidarności Walczącej Kornelem Morawieckim rozmawia Artur Adamski, Wrocław 2007.

Adamski A., Łątkowska M., Kornel Morawiecki, [w:] Encyklopedia „Solidarności”: opozycja w PRL 1976-1989, red. M. Łątkowska, t. 1, Warszawa-Katowice 2010, s. 288-289.

Bałtowski M., Miszewski M., Transformacja gospodarcza w Polsce, Warszawa 2019.

Borowski A., Łątkowska M., Karol Modzelewski, [w:] Encyklopedia „Solidarności”: opozycja w PRL 1976-1989, red. M. Łątkowska, t. 1, Warszawa-Katowice 2010, s. 286-287.

Borowski A., Łątkowska M., Władysław Frasyniuk, [w:] Encyklopedia „Solidarności”: opozycja w PRL 1976-1989, red. M. Łątkowska, t. 1, Warszawa-Katowice 2010, s. 115-116.

Dworaczek K., Chodziło mi o Polskę. Barbara Sarapuk 1940-2015, Wrocław 2016.

Dworaczek K., Jerzy Piórkowski, [w:] Encyklopedia „Solidarności”: opozycja w PRL 1976-1989, red. J. Olaszek, t. 4, Warszawa 2020, s. 344.

Dworaczek K., Podziemnie drukarstwo we Wrocławiu na przykładzie największych inicjatyw wydawniczych, „Dzieje Najnowsze”, R. 48 (2016), nr 4, s. 141-156.

Friszke A., Rewolucja Solidarności 1980-1981, Kraków 2014.

Grzelczyk K., Solidarność drukująca. Wrocławscy drukarze podziemni, Wrocław 2013.

Grzonkowski S., Sekcja Służby Zdrowia NSzZ „Solidarnośč" (Sekretariat Ochrony Zdrowia NSzZ „Solidarność"), [w:] Encyklopedia Solidarności. Opozycja w PRL 1976-1989, red. G. Waligóra, t. 2, Warszawa 2012, s. 400-402.

Kaczorowska K., Suleja W., Tak się nie godzi. Piotr Bednarz (1949-2009), Wrocław 2011.

Kamiński Ł., NSzZ „Solidarność” Region Dolny Śląsk, [w:] NSzZ „Solidarność” 1980-1989, tom 6: Polska południowa, red. Ł Kamiński, G. Waligóra, Warszawa 2010.

Kamiński Ł., Drogi do wolności Zagłębia Miedziowego, Legnica 2007.

Kaźmierska K., Waniek K., Autobiograficzny wywiad narracyjny. Metoda - technika - analiza, Łódź 2020. Kordas J., Kudłaszyk A., Sierpień '8o na Dolnym Ślasku, Wrocław 1997.

Modzelewski K., Zajeździmy kobytę historii. Wyznania poobijanego jeźdźca, Warszawa 2013.

Olaszek J., Drugi obieg wydawniczy w PR L i samizdat w innych państwach bloku sowieckiego: podobieństwa, różnice, wzajemne wpływy, [w:] Drugi obieg w PRL na tle samizdatu w państwach bloku sowieckiego po 1956 r., red. P. Gasztold-Seń, N. Jarska, J. Olaszek, Warszawa 2016, s. 16-60.

Olaszek J., Rewolucja powielaczy. Niezależny ruch wydawniczy w Polsce 1976-1989, Warszawa 2015.

Osiński K., Rybarczyk P., Kryzys bydgoski 1981. Przyczyny, przebieg, konsekwencje. Tom I. Monografia, Bydgoszcz-Gdańsk-Warszawa 2013. 
Pietkun P., Tu Radio Solidarność... Przyczynek do historii podziemnego Radia Solidarność 1982-1989, Warszawa 2018.

Rudka Sz., Poza cenzurą. Wrocławska prasa bezdebitowa 1973-1989, Warszawa-Wrocław 2001.

Sawicki W., Regionalny Komitet Strajkowy NSzz „Solidarność” Dolny Śląsk. XII 1981 - VI 1982, Wrocław 2011.

Solidarność Walcząca $w$ dokumentach, t. I: w oczach sB, red. Ł. Kamiński, W. Sawicki, G. Waligóra, Warszawa 2007.

Suleja W., Solidarność na Dolnym Śląsku 1980-2010, Wrocław 2010.

Surdy G., Brożek K., Solidarność Walcząca, Warszawa 2020.

Szaynok B., Maciej Zięba, [w:] Encyklopedia „Solidarności”: opozycja w PRL 1976-1989, red. M. Łątkowska, t. 1, Warszawa-Katowice 2010, s. 510.

Tak się nie godzi - zapis procesu Piotra Bednarza, Wrocław 1984.

Ziątkowski L., Na drodze do Solidarności. Wrocław w walce o demokrację i niepodległość 1976-1980, Wrocław 2010. 


\section{Summary}

Being active in the pro-democratic, anti-communist opposition in Poland during the 1980 s incurred numerous risks and often required making heroic sacrifices. Czesław Brokos' account provides a behind-the-scenes look at that kind of activity. Brokos was involved in Solidarity, both during its legal functioning in 1980-1981 and at the moment when the union went underground after the imposition of martial law in 1981. The account presented here provides numerous pieces of valuable information related to the practice of illegal, underground printing that is absent from other sources. It also contains the names of people who, like Czesław Brokos, are not widely known and do not appear on the pages of works of history. Thus, this account is a valuable historical source that proves that the phenomenon of Solidarity and other opposition groups was rooted in the work of thousands of anonymous activists. 